\title{
Terapie infekce aortální cévni protézy - editorial
}

\author{
Robert Staffa \\ Centrum cévních onemocněni a Cévni transplantační centrum, II. chirurgická klinika LF MU a FN u sv. Anny v Brně
}

\section{Komentář k | Editorial on}

\begin{abstract}
Bal'a P et al. Konzervativní terapie pozdní infekce aortální protézy. Vnitř Lék 2017; 63(2): 133-137.
\end{abstract}

Infekce aortální cévní protézy (aorto-iliako-femorální oblast) je jednou z nejzávažnějších a nejobávanějších komplikací v cévní chirurgii. Přesto, že se jedná o komplikaci relativně vzácnou (incidence 1-6\%) [1], stále představuje výzvu jak pro cévně-chirurgické týmy, tak také pro diagnostický management. $V$ diagnostice se kromě CT a MRI dnes již standardně využívá metoda FDG-PET/CT založená na detekci akumulace radioizotopem značených leukocytů v místě zánětu, v němž je patrná zvýšená utilizace glukózy $[2,3]$. Co se týče chirurgické léčby, v uplynulém období se etablovala řada postupů, ačkoliv společnými všem metodám jsou eradikace infekce, tedy nejlépe kompletní odstranění cévní protézy a následná tepenná extraanatomická nebo in situ rekonstrukce.

Nejčastěji používanou extraanatomickou cévní rekonstrukcí při infekci aorto-iliako-femorální protézy je axilo-(bi)femorální bypass pomocí cévní protézy vedené mimo oblast infektu. Ačkoliv je tato metoda považována za standardní, její výsledky, zvláště dlouhodobé, nejsou ideální. Důvodem je jednak poměrně vysoké riziko rekurentní infekce (až 20\%) [4], ale především riziko trombózy relativně "dlouhé" cévní protézy daného průměru a s tím spojené riziko amputace končetiny (až 43\%) [5]. Hlavní výhodou metody je možnost použití v urgentních stavech, jako je např. akutní krvácení z aorto-duodenální píštěle u pacienta s infekcí cévní protézy v aortální oblasti [6]. Infekce bývá často př́tomná také v oblasti třísel, $v$ takovém prípadě je podmínkou metody výtok na a. femoralis superficialis nebo raritně na a. poplitea [7].

Mezi in situ náhrady infikované aorto-iliako-femorální protézy patří např. bypass pomocí cévní protézy smáčené $v$ roztoku rifampicinu nebo cévní protézy impregnované solemi stř́bra, vždy v kombinaci s omentoplastikou. Tento postup je vhodný pouze u tzv. nízkovirulentních infekcí (tato skutečnost však často není předem známa) a jeho hlavní nevýhodou je vysoké riziko rekurentní infekce [8-10]. Další variantou in situ rekonstrukcí je použití „čerstvých“ nebo kryoprezervovaných tepenných alograftů. Riziko rekurentní infekce je ve srovnání s arteficiální náhradou výrazně nižší, nevýhodou metody je však riziko degradace alogenního štěpu a závislost na přitomnosti vhodného dárce nebo nabídce tkáňových bank $[11,12]$. Při hledání vhodnějšího materiálu pro in situ náhradu infikované aorto-iliako-femorální protézy se pozornost logicky obrátila na autogenní žílu, jejiž odolnost vưči infekci je obecně vysoká. Pokusy nahradit aorto-femorální úsek pomocí autogenní v. saphena magna nepřinesly dobré výsledky. Ačkoliv jsou známy ojedinělé úspěšné kazuistiky, ve větších a déle sledovaných souborech se poukazuje na vysoké riziko okluze takových rekonstrukcí (64-75\%) [13-15].

Přínosem při řešení infekce cévní protézy bylo použití autogenní femorální žíly. Průměr v. femoralis superficialis, která se za tím účelem odebírá v celé délce a často s částí v. poplitea, je v proximálním úseku 14-16 mm a distálně 8-12 mm. Je tak ideálním štěpem, který má všechny výhody autogenního materiálu včetně jeho odolnosti vůči infekci a zároveň splňuje požadavek na dostatečný průměr pro aorto-iliako-femorální pozici. Clagett v roce 1997 zveřejňuje práci, ve které hodnotí soubor 41 pacientů, u nichž byla infikovaná aorto-(bi)femorální cévní protéza nahrazena štěpem z pacientovy femorální žíly. Autor studie udává 100\% 5letou kumulativní sekundární průchodnost rekonstrukcí a nulový výskyt rekurentní infekce. Pouze u 4 pacientů po odběru femorální žíly pozoroval benigní edém končetiny, ve všech případech dobře kontrolovaný kompresivní punčochou, bez venózních ulcerací [16]. Podobně pozitivní výsledky zaznamenávají další autoři v USA a v Evropě [17-20]. Také některé aktuálnější práce potvrzují vynikající výsledky docílené autologní femorální vénou [21] a superioritu autologní femorální vény nad kryoprezervovanými alografty při léčbě infekce aortální cévní protézy [22].

$\mathrm{Na}$ Il. chirurgické klinice FN u sv. Anny v Brně se náhradě infikované cévní protézy $v$ aorto-iliako-femorální pozici pomocí autogenní v. femoralis superficialis programově věnujeme od roku 2007 [23-25] a naše dosavadní zkušenosti potvrzují velmi dobrý efekt metody.

V období od června roku 2007 do června 2016 jsme graft z autologních femorálních žil použili jako tepennou náhradu $v$ aorto-iliako-femorální pozici u 62 pacientů (49 mužů, 13 žen, průměrný věk 64,0 roků, rozmezí 30-79 let). 33krát jako náhradu infikované cévní protézy 
a 1krát jako náhradu infikovaného stentgraftu (12krát aorto-bifemorální, 9krát jednostranná aorto-femorální, 1krát aorto-aortální, 1krát axilo-bifemorální, 3krát náhrada jednoho raménka aorto-bifemorální protézy, 6 krát iliako-femorální protéza, 1 krát iliako-femorální protetický zkřižený bypass a 1krát iliakální stentgraft). U 28 pacientů se zvýšeným rizikem infekce (mykotické AAA, gangréna, pozitivní CRP, febrilie) byla provedena tepenná rekonstrukce v aorto-iliako-femorální pozici pomocí graftu z autologních femorálních žil jako primární výkon. Průměrná délka sledování souboru byla 32,5 \pm 28,1 měsíců, rozmezí 1-100 měsíců. 30denní mortalita byla 6,4 \% (4 pacienti - 8., 16., 21. a 21. pooperační den). V průběhu sledování souboru zemřelo dalších 10 pacientů bez souvislosti s výkonem, s funkčním žilním bypassem. V jednom případě $(1,6 \%)$ byla provedena časná reoperace pro selhání rekonstrukce. Dále došlo k jednomu uzávěru rekonstrukce po 5 měsících (1,6\%). V souboru byla u 5 pacientů $(8,0 \%)$ provedena amputace do 3 měsíců od výkonu z důvodu progrese ischemie periferie končetiny. V souboru nebyla pozorována plicní embolizace, rekurentní infekce, maligní edém končetiny po odběru femorální žily nebo aneuryzmatická dilatace žilního štěpu. Ve 4 případech (6,4 \%) byl pozorován přechodný benigní otok odběrové končetiny, dobře kontrolovaný kompresivní punčochou. Výsledky naší studie hovoři ve prospěch metody řešení infekce aortální cévní protézy autologní femorální žilou ve srovnání s jinými modalitami. Riziko rekurentní infekce je minimální, dlouhodobá průchodnost graftů vynikající. Obava z otoku dolní končetiny po odběru femorální žíly je neopodstatněná.

Za určitý posun v problematice léčby infekce aortální cévní protézy můžeme považovat možnost využití nových biologických materiálů. V roce 2016 jsme tak poprvé v ČR úspěšně řešili infekci aortální cévní protézy pomocí bifurkačního aorto-bifemorálního graftu z bovinního perikardu. Tato metoda významně mění možnosti léčby této komplikace, ve srovnání s femorálními žilami zásadně zkracuje operační čas. První výsledky několika evropských pracovišt', která tuto metodu již využila, jsou velmi nadějné, nicméně na finální vyhodnocení střednědobých a dlouhodobých výsledků bude nutné ještě počkat.

V poslední době se také stále častěji objevují práce, podle kterých byla infekce cévní protézy zvládnuta pomocí vakuové terapie. Nejlepších výsledků bylo dosaženo v oblasti třísla a v prípadech, v nichž se jednalo o časnou infekci cévní protézy. Léčba infekce aortální cévní protézy konzervativním způsobem, takjakji popsali autoři článku Konzervativní terapie pozdní infekce aortální protézy, je raritní modalitou, o to větší zasluhuje pozornost.

Na závěr je možné konstatovat, že existuje řada postupů jak léčit infekci aortální cévní protézy. Ideální je mít k dispozici všechny známé možnosti léčby a volbu konkrétní modality přizpůsobit stavu pacienta.

\section{Literatura}

1. Herman J, Utíkal $P$, Sekanina $Z$ et al. Infekce náhrad abdominální aorty. Rozhl Chir 2009; 88(7): 349-352.
2. Špaček M, Bělohlávek O, Votrubová J et al. Diagnostics of "non-acute" vascular prosthesis infection using 18F-FDG PET/CT: our experience with 96 prostheses. Eur J Nucl Med Mol Imaging 2009; 36(5): 850858. Dostupné z DOI: <http://dx.doi.org/10.1007/s00259-008-1002-z>.

3. Fukuchi $K$, Ishida $Y$, Higashi $M$ et al. Detection of aortic graft infection by fluorodeoxyglucose positron emission tomography: Comparison with computed tomographic findings. J Vasc Surg 2005; 42(5): 919-925.

4. Bacourt F, Koskas F. [French University Association for research in surgery]. Axillobifemoral bypass and aortic exclusion for vascular septic lesions: a multicenter retrospective study of 98 cases. Ann Vasc Surg 1992; 6(2): 119-126.

5. Quinones-Baldrich WJ, Hernandes JJ, Moore WS. Long-term results following surgical management of aortic graft infection. Arch Surg 1991; 126(4): 507-511.

6. Wasiková S, Staffa R, Kř́ž Z et al. Léčba infekce cévní protézy a aorto-enterické píštěle jako pozdní komplikace rekonstrukčního výkonu na abdominální aortě - kazuistika. Rozhl Chir 2007; 86(10): 522-524.

7. Pluháčková $H$, Staffa $R$, Vlachovský $R$ et al. Ojedinělý případ dlouhodobé průchodnosti axillo-bipopliteálního bypassu - kazuistika. Rozhl Chir 2011; 90(10): 575-578.

8. Chiche L, Pitre J, Sarfati PO. In situ repair of a secondary aorto-appendiceal fistula with a rifampin-bonded Dacron graft. Ann Vasc Surg 1999; 13(2): 225-228.

9. Batt $M$, Magne JL, Alric $P$ et al. In situ revascularization with silver-coated polyester grafts to treat aortic infection: early and midterm results. J Vasc Surg 2003; 38(5): 983-989.

10. Oderich G, Bower T, Cherry K et al.: Evolution from Axillofemoral to In Situ Prosthetic Reconstruction for the Treatment of Aortic Graft Infections at a Single Center. J Vasc Surg 2006; 43(6): 1166-1174.

11. Noel AA, Gloviczki P, Cherry KJ Jr et al: Abdominal aortic reconstruction in infected fields: early results of the United States cryopreserved aortic allograft registry. J Vasc Surg 2002; 35(5): 847-852.

12. Kieffer $E$, Gomes $D, C$ hiche $L$ et al. Allograft replacement for infrarenal aortic graft infection: early and late results in 179 patients. J Vasc Surg 2004; 39(5): 1009-1017.

13. Clagett GP, Bowers BL, Lopez-Viego MA et al. Creation of neo-aortoiliac system from lower extremity deep and superficial veins. Ann Surg 1993; 218(3): 239-248.

14. Seeger JM, Wheeler JR, Gregory RT et al. Autogenous graft replacement of infected prosthetic grafts in the femoral position. Surgery 1983; 93(1 Pt 1): 39-45.

15. Jicha DL, Reilly LM, Kuestner LM et al. Durability of cross-femoral grafts after aortic graft infection: the fate of autogenous conduits. J Vasc Surg 1995; 22(4): 393-405; discussion 406-407.

16. Clagett GP, Valentine RJ, Hagino RT. Autogenous aortoiliac/femoral reconstruction from superficial femoral-popliteal veins: feasibility and durability. J Vasc Surg 1997; 25(2): 255-266, discussion 267-270.

17. Nevelsteen A, Lacroix $H$, Suy R. Autogenous reconstruction with lower extremity deep veins: an alternative treatment of prosthetic infection after reconstructive surgery for aortoiliac disease. J Vac Surg 1995; 22(2): 129-134.

18. Franke $S$, Voit R. The superficial femoral vein as arterial substitute in infections of the aortoiliac region. Ann Vasc Surg 1997; 11(4): 406-412.

19. Gordon LL, Hagino RT, Jackson MR et al. Complex aortofemoral prosthetic infections: the role of autogenous superficial femoropopliteal vein reconstruction. Arch Surg 1999; 134(6): 615-620; discussion 620-621.

20. Gibbons CP, Ferguson CJ, Edwards $\mathrm{K}$ et al. Use of superficial femoropopliteal vein for suprainguinal arterial reconstruction in the presence of infection. B J Surg 2000; 87(6): 771-776.

21. Ehsan O, Gibbons CP. A 10-year experience of using femoro-popliteal vein for revascularization in graft and arterial infections. Eur J Vasc Endovasc Surg 2009; 38(2): 172-179. Dostupné z DOI: <http://dx.doi.org/10.1016/j.ejvs.2009.03.009>.

22. Boyle JR. Superficial Femoral Vein is Superior to Cryopreserved Allografts for in situ Aortic Reconstruction. Eur J Vasc Endovasc 
Surg 2014; 48(3): 300. Dostupné z DOI: <http://dx.doi.org/10.1016/j. ejvs.2014.05.024>.

23. Staffa R. Tepenná náhrada odebraná z hlubokého žilního systému - prioritní operace v ČR. Medical Tribune 2007; 3(21): A1.

24. Staffa R, Kříž Z, Vlachovský R. Hluboká žíla dolní končetiny jako tepenná náhrada při řešení infekce cévní protézy. Rozhl Chir 2008; 87(4): 186-189.

25. Staffa R, Kř́ž Z, Vlachovský $R$ et al. Autogenní vena femoralis superficialis jako náhrada infikované aorto-iliako-femorální cévní protézy. Rozhl Chir 2010; 89(1): 39-44.

\section{prof. MUDr. Robert Staffa, Ph.D. $\triangle$ robert.staffa@fnusa.cz}

Centrum cévních onemocnění a Cévní transplantační centrum, II. chirurgická klinika LF MU a FN u sv. Anny v Brně www.fnusa.cz

Doručeno do redakce 19. 1. 2017

\section{Pozvánka}
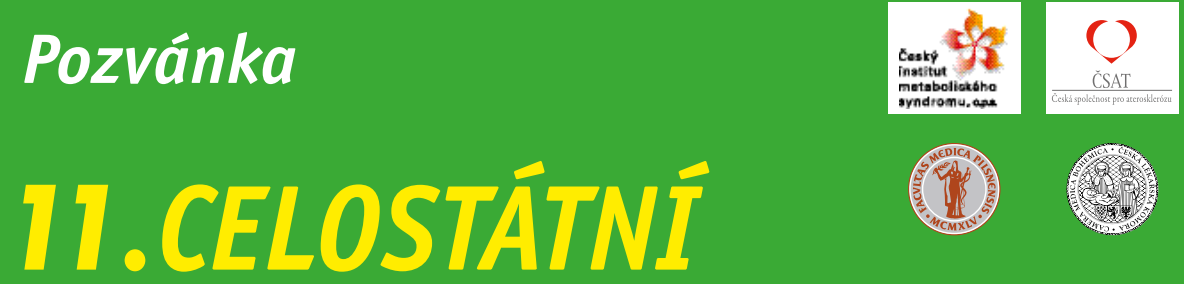

SEMINÁR̆ ČIMS, o.p.S.,

České iniciativy R3i

a České společnosti pro aterosklerózu

a seminář 2. interní kliniky Lékařské fakulty

v Plzni (UK Praha)

ve spolupráci s Českou lékařskou komorou

\section{3. března 2017}

\section{hotel ANGELO, U Prazdroje 6, PLZEŇ}

Odborná akce je pořádána v rámci celoživotního vzdělávání lékařů dle Stavovského předpisu ČLK č. 16.

Tato akce je zařazena do celoživotního vzdělávání nelékařských zdravotnických pracovníků a bude ohodnocena príslušným počtem kreditů, dle Vyhlášky MZ ČR č. 423/2004 Sb. ve znění pozdějších předpisů.

Pro účastníky z Prahy je zajištěna bezplatná autobusová doprava do Plzně a zpět. Podrobnosti $k$ dopravě jsou na www.gsymposion.cz. V prípadě zájmu uvedte prosím současně s Vaší registrací.

Organizační zajištění:

Galén-Symposion s.r.o., Břežanská 10, 10000 Praha 10, tel.: 222518535

Registrace na: www.gsymposion.cz nejpozději do 20. března 2017 